\title{
Effects of a minimal reminder intervention to reduce the length of urinary catheterization and intravenous fluids therapy for internal medicine inpatients: a parallel controlled clinical trial
}

\author{
Jesús Díez-Manglano *1,2,3, Claudia Palazón-Fraile ${ }^{1}$, María Sevil-Puras ${ }^{1,2}$, María-Jesús Arnal-Longares ${ }^{1}$, Sofía \\ Terrén-Portolés ${ }^{1}$, Susana Alcubierre-Iriarte ${ }^{1}$ \\ ${ }^{1}$ Internal Medicine Department, Hospital Royo Villanova, Zaragoza, Spain \\ ${ }^{2}$ Research Group on Comorbidity and polypathology in Aragón, Aragón Health Sciences Institute, Zaragoza, Spain \\ ${ }^{3}$ Department of Medicine, Dermatology and Psychiatry, University of Zaragoza School of Medicine, Zaragoza, Spain
}

Received: October 8, 2015

DOI: $10.5430 /$ jnep.v6n7p74
Accepted: December 23, $2015 \quad$ Online Published: March 3, 2016

URL: http://dx.doi.org/10.5430/jnep.v6n7p74

\begin{abstract}
Objective: To assess the effectiveness of a twice-weekly simple reminder intervention in shortening the duration of urinary catheterization and intravenous fluid therapy.

Methods: Design: Parallel, controlled clinical trial. Setting: Two internal medicine wards. Patients: Patients admitted to the Internal Medicine Department since October 2010 and 3, 7 and 12 months later. Intervention: A twice-weekly simple reminder intervention during the meetings of the medical-nursing team in one ward (intervention group) and no intervention in the other (control group). Measurements: Age, sex, living at home or in a nursing residence, Barthel index, Norton scale, use and duration of urinary catheterization and intravenous fluid therapy, presence of pressure ulcers, onset of delirium, Major Diagnostic Category, and length of stay.

Results: 747 patients were included. On 265 of them (35.4\%) urinary catheterization was used. Patients in control group had urinary catheters inserted more frequently $(39.1 \% v s .31 .7 \% ; p=.03)$ and for a longer time [median (interquartile range) $5(8) v s$. 4 (6) days; $p=.007]$; also, the catheter was left in place at discharge more frequently $(15.2 \% v s .10 .1 \% ; p=.04)$. Intravenous fluid therapy was used on $519(69 \%)$ patients. There were no differences in use between both groups, but it was for a longer period in control group [4 (5) vs. 3 (5) days; $p=.001$ ].

Conclusions: A simple face-to-face intervention during the meetings of the medical-nursing team with a twice a week reminder to withdraw unnecessary urinary catheters and intravenous fluid therapy efficiently reduces the duration of such treatments.
\end{abstract}

Key Words: Urinary catheterization, Intravenous fluid therapy, Reminder intervention, Internal medicine

\section{INTRODUCTION}

Approximately $25 \%$ of all patients admitted to a hospital have an indwelling urinary catheter inserted ${ }^{[1]}$ and in up to $50 \%$ of the cases there is no proper medical indication for it. ${ }^{[2,3]}$ Urinary catheterization is a very frequent cause of infection, and the longer use is prolonged, the greater Spain. 
the patients' possibility of contracting a urinary infection. ${ }^{[4]}$ Catheter-associated urinary tract infections are associated with morbidity, mortality, longer hospital stays and higher costs. ${ }^{[5-8]}$ In United States the attributable annual deaths from catheter-associated urinary tract infections were estimated to be over $13,000 .{ }^{[6]}$

Up to half of inpatients are treated with intravenous fluids through a peripheral venous catheter. Phlebitis, infection and obstruction are complications associated to this procedure. The length of time the catheter remains in place is the main factor associated with subsequent onset of phlebitis. ${ }^{[9,10]} \mathrm{A}$ recent study showed a $35 \%$ rate of phlebitis and infiltration. ${ }^{[11]}$ The peripheral catheters are one of the most frequent causes of nosocomial bacteraemia in hospitals. ${ }^{[12]}$ In a multicenter study the cost of a catheter-related bloomstream infection was estimated to be $\$ 20,647$ in $2011 .^{[13,14]}$

Patients' safety while receiving health care is a concern for patients, ${ }^{[15,16]}$ governments ${ }^{[17]}$ and health institutions. ${ }^{[18]}$ Several strategies have been developed in order to reduce complications associated with urinary and peripheral intravenous catheters. ${ }^{[11,19]}$

The aim of our study was to determine whether a minimal reminder intervention might reduce the duration of both urinary catheterizations and use of intravenous fluid therapy.

\section{MATERIALS AND METHODS}

\subsection{Design and setting}

IMPIMI (Intervención Mínima en Pacientes Ingresados en Medicina Iinterna), acronym in Spanish for "minimal intervention on internal medicine inpatients", is a parallel controlled clinical trial. The study was conducted in Royo Villanova Hospital in Zaragoza, Spain. The hospital attends a population of 200,000 people. There are two internal medicine nursing units, with 30 beds each. In one of the wards, starting October 2010, the therapeutic team of doctors and nurses would hold a Monday to Friday daily meeting. Twice a week, during those meetings one of the authors (JDM) proceeded to a minimal reminder intervention to remove indwelling urinary catheter, stops intravenous fluid therapy, monitor the appearance of pressure ulcers, and detect early the occurrence of delirium. The intervention was a general, not patient-specific, simple verbal reminder. This reminder was continuously delivered by the same person, or in absence of it, by other member of the team. The person delivering the reminder had not a hierarchical relationship to the staff in the meeting. Such interventions were not carried out in the other ward. There were no incentives for this intervention. Retrospectively, we went through the nursing records and administrative data of patients admitted in the

Published by Sciedu Press
Internal Medicine department in October 2010 (beginning the intervention), January 2011 (3 months after interventions began), May 2011 (7 months after) and October 2011 (1 year after). We chose those months to avoid the factor of confusion that staff changes during the Easter and the Summer holiday periods might have introduced. Patients were divided into two groups: those attended to by the team carrying out the reminder intervention (group I) and those attended to by other teams who didn't (group II).

\subsection{Measurements}

At admission, a nurse interviewed all patients or their caregivers to check functional and mental status. For each patient, data concerning age, gender, living at home or in a nursing residence, ability to carry out basic daily living tasks, risk of presenting pressure ulcers, use of intravenous fluid therapy, days on intravenous fluid therapy, use of urinary catheterization, duration of urinary catheterization, presence of pressure ulcers, onset of delirium during their stay, Major Diagnostic Category at discharge and number of stays at hospital were collected. We used Barthel index to measure ability to carry out basic daily living tasks. ${ }^{[20]}$ Barthel index scores range between 0 and 100; the higher the score, the more independent the person. To measure the risk of developing pressure ulcers we used the Norton scale ${ }^{[21]}$ which reflects five parameters: physical condition, mental condition, activity, mobility, and incontinence. The scale scores range between 0 and 20: the lower the score, the higher the risk.

The study was approved by the Clinical Research Ethics Committee of Aragón (PI 12/0009).

\subsection{Statistical analysis}

In previous analysis carried out in our department, the average duration of urinary catheterization was 8 days, and 5 days for IV fluid therapy. For a bilateral test, and assuming a confidence level of $95 \%$, a statistical power of $90 \%$ and an accuracy of 2 days and a variance of 49 for urinary catheterization, and an accuracy of 2 days and a variance of 16 for fluid therapy, the samples needed were of 258 patients with indwelling urinary catheter and 336 with intravenous fluid therapy.

The Kolmogorov-Smirnov test was used to determine whether variables had a normal distribution or not. A descriptive analysis of the sample was carried out using medians and interquartile ranges for quantitative variables, and percentages for categorical ones. Comparisons between variables were made using the Mann-Whitney test for quantitative ones, and the Chi-square test for categorical ones. The statistical significance level was established at $p<.05$.

Statistical analysis was performed using the software G-Stat 


\section{0 (www.e-biometria.com).}

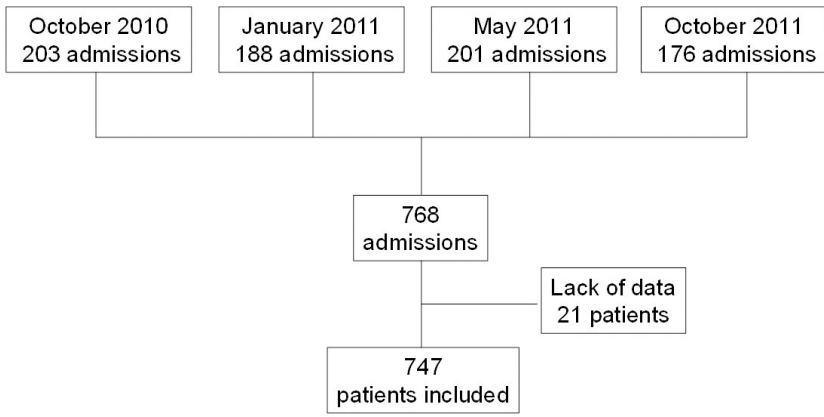

Figure 1. Flowchart of patients included

\section{Results}

During the periods of study, there were 768 admissions, of which 747 were included. Figure 1 shows the flowchart of included patients. Their characteristics are presented in table 1. Patients in group II scored lower in the Norton scale [17 (8) vs. 15 (8); $p=.009]$.

\subsection{Urinary catheterization}

During hospitalization, 265 patients $(35.4 \%)$ had an indwelling urinary catheter applied. Of those patients, 172 (64.9\%) had it inserted in Emergency Department, 60 (22.6\%) in the Internal Medicine ward and 29 (10.9\%) already had a permanent catheter at admission (see Figure 2). Patients in group II bore an indwelling urinary catheter more frequently (39.1 vs. $31.7 \% ; p=.03$ ), they did so for a longer time (5 (8) vs. 4 (6) days; $p=.007$ ), and more of them remained catheterized at discharge $(15.2 \% v s .10 .1 \% ; p=$ $.04)$.

Table 1. Clinical characteristics of patients

\begin{tabular}{|c|c|c|c|c|}
\hline & $\begin{array}{l}\text { Group I } \\
(n=366)\end{array}$ & $\begin{array}{l}\text { Group II } \\
(n=381)\end{array}$ & $p$ & $\begin{array}{l}\text { Total } \\
(n=747)\end{array}$ \\
\hline Age* & $79(18)$ & $80(15)$ & .36 & $79(16)$ \\
\hline Male & $173(47)$ & $183(48)$ & & $356(48)$ \\
\hline Female & $191(52)$ & $198(52)$ & .89 & $389(52)$ \\
\hline Living in nursing residence & $81(22)$ & $92(24)$ & .49 & $173(23)$ \\
\hline Barthel index* & $90(70)$ & $75(70)$ & .12 & $80(70)$ \\
\hline Norton scale*\$ & $17(8)$ & $15(8)$ & .009 & $16(8)$ \\
\hline Delirium & $50(14)$ & 47 (12) & .59 & $97(13)$ \\
\hline Pressure ulcers & $45(12)$ & $62(16)$ & .12 & $107(14)$ \\
\hline Urinary catheter & $111(32)$ & 149 (39) & .03 & $265(35)$ \\
\hline Intravenous fluid therapy & $251(69)$ & $268(70)$ & .60 & $519(69)$ \\
\hline \multicolumn{5}{|l|}{ Major diagnostic categories } \\
\hline Nervous system & $35(9.6)$ & $34(8.9)$ & .74 & $69(9.2)$ \\
\hline Eye & $1(0.3)$ & $3(0.8)$ & .36 & $4(0.5)$ \\
\hline Ear, nose, mouth and throat & $3(0.8)$ & $3(0.8)$ & 1.00 & $6(0.8)$ \\
\hline Respiratory system & $75(20.5)$ & $89(23.4)$ & .34 & $164(21.9)$ \\
\hline Circulatory system & $49(13.4)$ & $51(13.4)$ & 1.00 & $100(13.4)$ \\
\hline Digestive system & 73 (19.9) & $60(15.7)$ & .13 & $133(17.8)$ \\
\hline Hepatobiliary system and pancreas & $24(6.6)$ & $34(8.9)$ & .24 & $58(7.8)$ \\
\hline Musculoskeletal system & $5(1.4)$ & $11(2.9)$ & .16 & $16(2.1)$ \\
\hline Skin, subcutaneous tissue and breast & $7(1.9)$ & $9(2.4)$ & .64 & $16(2.1)$ \\
\hline Endocrine system & $15(4.1)$ & $12(3.1)$ & .46 & $27(3.6)$ \\
\hline Kidney and urinary tract & $24(6.6)$ & $35(9.2)$ & .19 & $59(7.9)$ \\
\hline Blood & $13(3.5)$ & 7 (1.8) & .15 & $20(2.7)$ \\
\hline Mental diseases and disorders & $5(1.4)$ & $6(1.6)$ & .82 & $11(1.5)$ \\
\hline Myeloproliferative disorders and poorly differentiated neoplasms & $4(1.1)$ & $3(0.8)$ & 67 & $7(0.9)$ \\
\hline Human immunodeficiency virus infection & $3(0.8)$ & $2(0.5)$ & .61 & $5(0.7)$ \\
\hline Other diseases & $9(2.4)$ & $5(1.3)$ & .26 & $14(1.8)$ \\
\hline
\end{tabular}

Note. Data are presented as *median (interquartile range) or n (\%); \$ Data from 670 patients. 


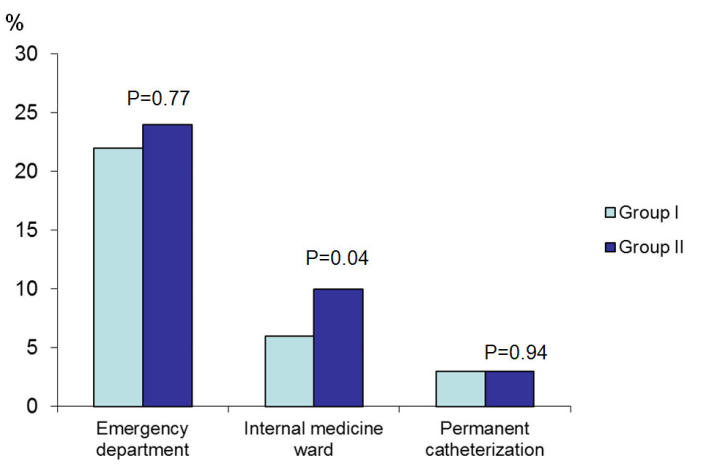

Figure 2. Department of insertion of indwelling urinary catheters

\subsection{Intravenous fluid therapy}

Intravenous fluid therapy was used on 519 patients (69\%). There were no differences between groups in this (see Figure
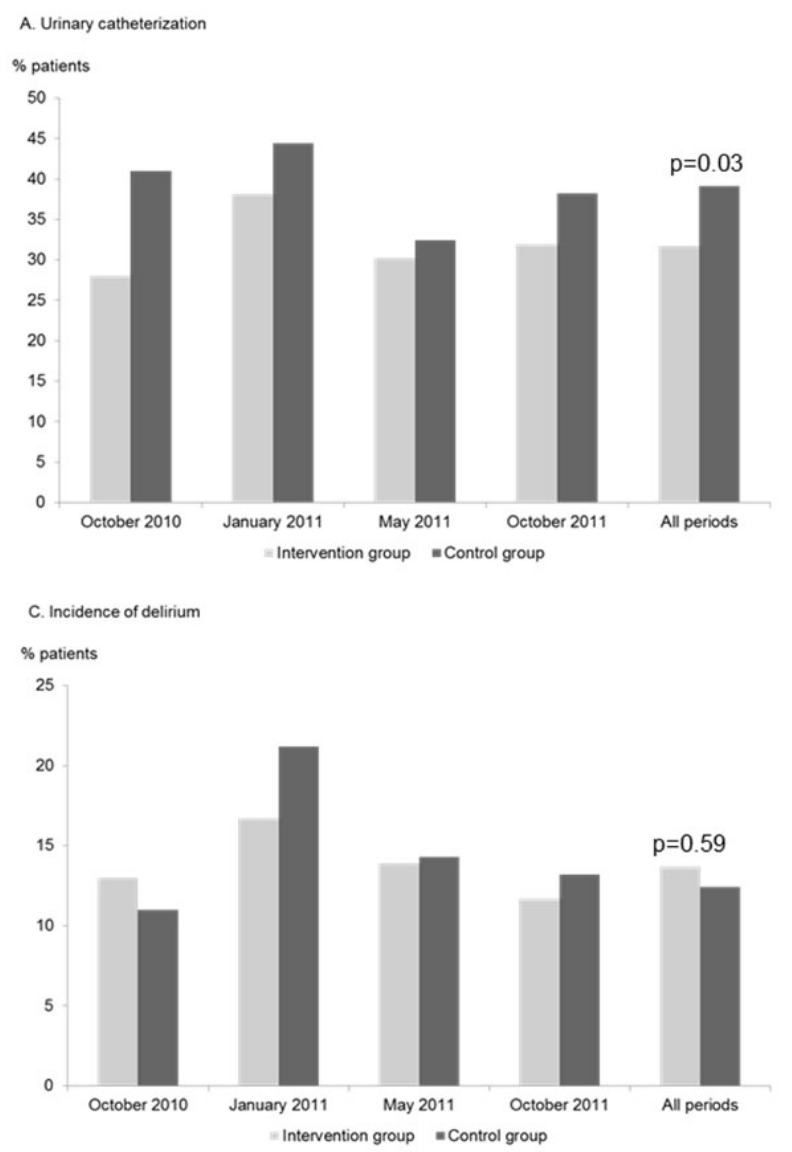

3), but its duration was longer in group II (4 (5) vs. 3 (5) days; $p=.001$ ) (see Figure 4).

There was no difference in the onset of delirium and the occurrence of pressure ulcers (see Figure 3). The hospital stay tended to be longer in group II, though not to a statistically significant degree (8 (8) vs. 7 (8) days: $p=.06$ ).

\section{Discussion}

In our study, a simple reminder intervention to remove indwelling urinary catheter and stop intravenous fluid therapy proved efficient in reducing the duration of these procedures.

Infections of the urinary tract and those associated with intravenous catheters pose a major challenge for nurses and doctors in hospitals. Furthermore, they are an important cause of morbidity and lengthen the patients' hospital stays, thus increasing health care costs. ${ }^{[10,22]}$
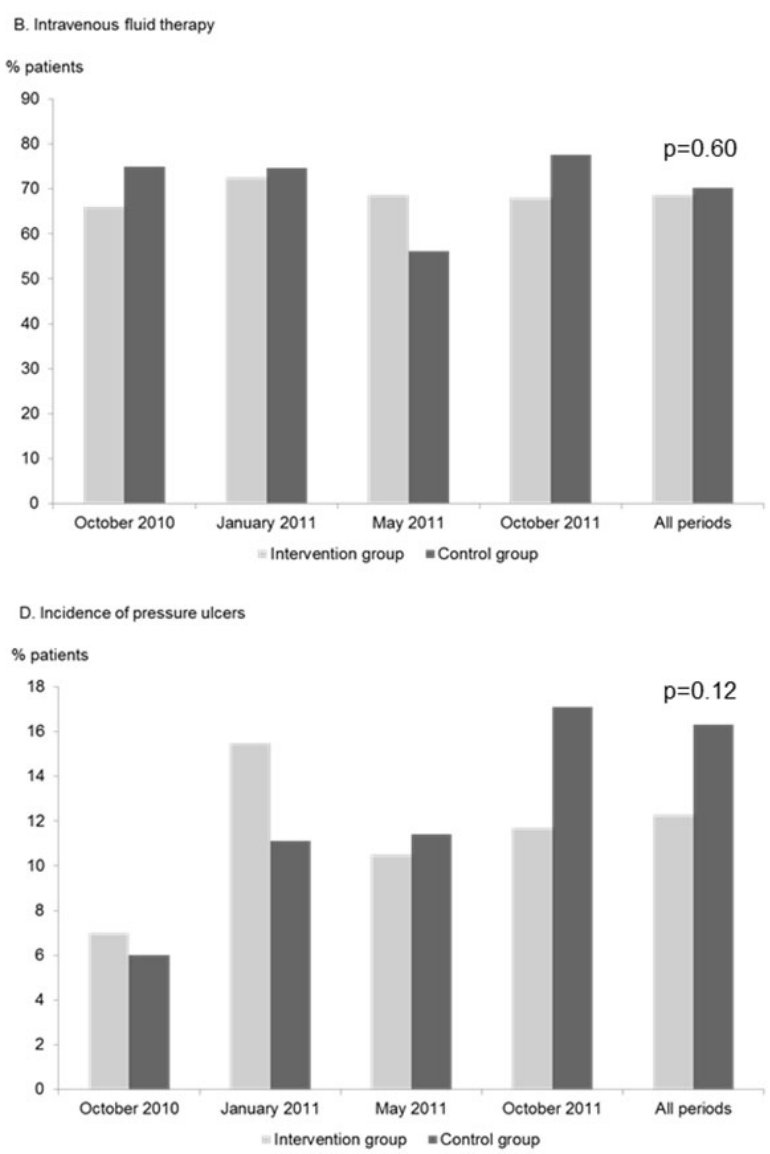

Figure 3. Patients with urinary catheterization, intravenous fluid therapy, delirium and pressure ulcers

Patients with an indwelling urinary catheter in place experience a loss in personal autonomy and dignity. ${ }^{[23]}$ Our intervention effectively reduced its use by $7.4 \%$. Also, it shortened the duration of catheterization by one day, and reduced by $5.1 \%$ the number of patients discharged with a urinary catheter. We didn't gather data regarding patients' satisfaction, but it can be assumed it is greater the earlier catheters are withdrawn. 

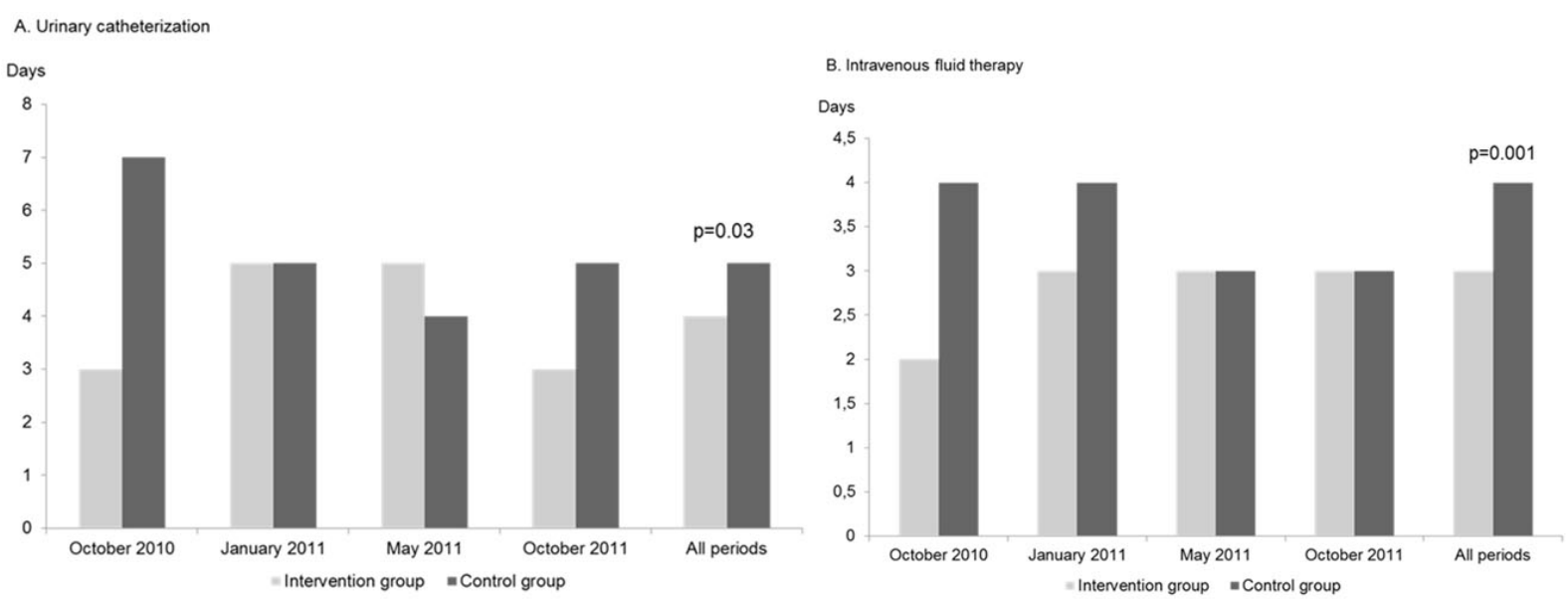

Figure 4. Duration of urinary catheterization and intravenous fluid therapy

Automatic reminders provided by virtual computer systems found a $6 \%$ reduction in urinary catheterization after one year. ${ }^{[24]}$ In France, daily reminders from nurses to physicians to remove unnecessary urinary catheters four days after insertion significantly decreased the duration of catheterization in orthopaedic and cardiovascular surgery wards but not in neurology, neurosurgery and geriatrics one ${ }^{[4]}$ In this study an infection control nurse physically visited the participating wards every day and identified with the nursing staff catheterized patients. We think that the shared decisions in the therapeutic team of doctors and nurses daily meeting may be more effective.

Doctors frequently ignore or forget that their patients are using an indwelling urinary catheter, and their use is prolonged unnecessarily. ${ }^{[25]}$ Different reminder systems have proved effective in reducing the duration of urinary catheterizations. $^{[26,27]}$ Educational reminders, face-to-face ${ }^{[3,4]}$ or paper-based, ${ }^{[28,29]}$ have been used to inform doctors that their patients are using a indwelling urinary catheter and aim to encourage their removal. Virtual computer systems that provide automatic reminders for catheter withdrawal have also been used. ${ }^{[2,30]} \mathrm{A}$ recent review showed that interventions directed by nurses or implemented by computer systems help reduce the duration of urinary catheterizations and potential infections of the urinary tract. ${ }^{[31]}$ To have a nurse providing written reminders has effectively and significantly reduced the number of catheterized inpatients. ${ }^{[32]}$ Moreover, none of these interventions were followed by a greater need of recatheterizations after withdrawing the catheter. ${ }^{[27]}$

In our study, two thirds of urinary catheters were inserted in the Emergency Department. Educational interventions should probably be instituted in this department to rigorously assess the need to insert a urinary catheter on patients. Constant interventions from the moment of their admission until they leave the hospital once discharged would result in greater benefits in terms of reduction of morbidity, mortality and health costs and improvement of the satisfaction and quality of life of the patients.

Urinary catheterization during admission in patients who had not previously been catheterized in Emergency Department was lower in the intervention group. Hence, by implementing the simple "reminder intervention" not only does it reduce the duration of catheterizations, but it also discourages their unnecessary use.

Venous catheters time in situ is the main risk factor for the development of thrombophlebitis. ${ }^{[9,10]}$ Routine replacement every 48 hours has been proposed to limit the phlebitides and obstructions associated with them. ${ }^{[33]}$ Nevertheless, recent studies have proved such measures to be ineffective. ${ }^{[11,34]}$ In intensive care units, daily awareness interventions by doctors have succeeded in reducing the duration of central venous catheterization with a tendency to reduce infections. ${ }^{[35]}$ There is scarce evidence on similar interventions with peripheral venous catheters. Ours didn't assess the presence of phlebitides or catheter obstructions, since that was not considered our aim. Nevertheless, reducing the duration of intravenous fluid therapy may possibly have resulted in reducing their incidence as well. New studies will be needed to verify these possible results.

Our study had some limitations. Firstly, it is not randomized; besides, the retrospective analysis was limited to one centre. Secondly, the consequences of catheter withdrawal weren't assessed, and urinary and venous recatheterization might have been necessary in some cases.

In conclusion, a simple face-to-face intervention during the meetings of the doctors and nurses team with a twice a week reminder to remove unnecessary indwelling urinary catheter 
and stop intravenous fluid therapy is effective in reducing the duration of both treatments. It's a simple, non-costly intervention that allows discussion between team members when doubts arise about the need to prolong these treatments.
In addition, the interventions were well accepted by both doctors and nurses.

\section{Conflicts of InTEREST Disclosure}

The author declares that there is no conflict of interest.

\section{REFERENCES}

[1] Gokula RR, Hickner JA, Smith MA. Inappropiate use of urinary catheters in elderly patients at a midwestern community teaching hospital. American Journal of Infection Control. 2004; 32(9): 196-199. PMid:15175612. http://dx.doi.org/10.1016/j.aji c. 2003.08 .007

[2] Munasinghe RL, Yazdani H, Siddique M, et al. Appropriateness of use of indwelling urinary catheters in patients admitted to the medical service. Infection Control and Hospital Epidemiology. 2001; 22(10): 647-649. PMid:11776352. http://dx.doi.org/10.1086/50183 7

[3] Fakih MG, Watson SR, Greene T, et al. Reducing inappropriate urinary catheter use. A statewide effort. Archives of Internal Medicine. 2010; 172(3): 255-260. PMid:22231611. http://dx . doi .org/10. 1001/archinternmed. 2011.627

[4] Crouzet J, Bertrand X, Venier AG, et al. Control of the duration of urinary catheterization: Impact on catheter-associated urinary tract infection. The Journal of Hospital Infection. 2007; 67(3): 253-257. PMid:17949851. http://dx.doi.org/10.1016/j.jhi n. 2007.08 .014

[5] Scott RD. The direct medical costs of healthcare-associated infections in U.S. Hospitals and the benefits of prevention, 2009. Division of Healthcare Quality Promotion, National Center for Preparedness, Detection, and Control of Infectious Diseases, Coordinating Center for Infectious Diseases, Centers for Disease Control and Prevention, [Internet]. Available from: http://www.cdc.gov/HAI/pdfs/hai /Scott_CostPaper.pdf (21 December 2015 date last accessed).

[6] Klevens RM, Edwards JR, Richards CL Jr, et al. Estimating health care-associated infections and deaths in U.S. hospitals, 2002. Public Health Reports. 2007; 122(2): 160-166.

[7] Apisarnthanarak A, Rutjanawech S, Wichansawakun S, et al. Initial inappropriate urinary catheters use in a tertiary-care center: incidence, risk factors, and outcomes. American Journal of Infection Control. 2007; 35(9): 594-599. PMid:17980238. http: //dx.doi.org/10.1016/j.ajic.2006.11.007

[8] Tambyah PA, Knasinski V, Maki DG. The direct costs of nosocomial catheter-associated urinary tract infection in the era of managed care. Infection Control \& Hospital Epidemiology. 2002; 23(1): 27-31. PMid:11868889. http://dx.doi.org/10.1086/501964

[9] Catney MR, Hillis S, Wakefield B, et al. Relationship between peripheral intravenous catheter Dwell time and the development of phlebitis and infiltration. Journal of Infusion Nursing. 2001; 24(5): 332-341. PMid:11575049. http://dx.doi .org/10.1097/00129 804-200109000-00008

[10] White SA. Peripheral intravenous therapy-related phlebitis rates in an adult population. Journal of Intravenous Nursing. 2001; 24(1): 19-24. PMid:11836840.

[11] Webster J, Clarke S, Paterson D, et al. Routine care of peripheral intravenous catheters versus clinically indicated replacement: randomised controlled trial. British Medical Journal. 2008; 337: a339. PMid:18614482.

Published by Sciedu Press
[12] Pujol M, Hornero A, Saballs M, et al. Clinical epidemiology and outcomes of peripheral venous catheter-related bloodstream infections at a university-affiliated hospital. The Journal of Hospital Infection. 2007; 67(1): 22-29. PMid:17719678. http://dx.doi.org/10.10 $16 / \mathrm{j} \cdot \mathrm{jhin} .2007 .06 .017$

[13] Kilgore M, Brossette S. Cost of bloodstream infections. American Journal of Infection Control. 2008; 36(10): S172. e1-3. PMid:19084149.

[14] Hollenbeak CS. The cost of catheter-related bloodstream infections: implication nfor the value of prevention. Journal of Infusion Nursing. 2011; 34(5): 309-313. PMid:21915004.

[15] Canadian Patient Safety Institute [Internet]. Available from: http://www . patientsafetyinstitute.ca/English/ Pages/default.aspx (21 December 2015 last accessed). http://dx.doi.org/10.1097/NAN.0b013e3182285e43

[16] VA National Center for Patient Safety. United States Department of Veterans Affairs [Internet]. Available from: http://www.patien tsafety.va.gov/(21 December last accessed).

[17] Ministerio de Sanidad, Servicios Sociales e Igualdad. Seguridad del paciente [Internet]. Available from: http://www.segurida ddelpaciente.es/es/presentacion/ (21 December 2015 last accessed).

[18] World Health Organization. Patient safety [Internet]. Available from: http : //www . who . int/patientsafety/en/ (21 December 2015 last accessed).

[19] Rothfeld AF, Stickley BS. A program to limit urinary catheter use at an acute care hospital. American Journal of Infection Control. 2010; 38(7): 568-571. PMid:20381918. http://dx.doi.org/10.1016 /j.ajic.2009.12.017

[20] Mahoney FI, Barthel DW. Functional evaluation: the Barthel index. Maryland State Medical Journal. 1965; 14: 61-65.

[21] Norton D, McLaren R, Exton-Smith AN. An investigation of geriatric problems in hospital (3rd ed). London: Churchill-Livingstone, 1979.

[22] Saint S. Clinical and economic consequences of nosocomial catheterrelated bacteriuria. American Journal of Infection Control. 2000; 28(1): 68-75. PMid:10679141. http://dx.doi.org/10.1016/S 0196-6553(00)90015-4

[23] Bhardwaj R, Pickard R, Carrick-Sen D, et al. Patients' perspectives on timing of urinary catheter removal after surgery. British Journal of Nursing. 2012; 21(18): S4, S6-9. PMid:23123810.

[24] Topal J, Conklin S, Camp K, et al. Prevention of nosocomial catheter-associated urinary tract infections through computerized feedback to physicians and a nurse-directed protocol. American Journal of Medical Quality. 2005; 20(3): 121-126. PMid:15951517. http://dx.doi.org/10.1177/1062860605276074

[25] Saint S, Wiese J, Amory JK, et al. Are physicians aware of which of their patients have indwelling urinary catheters? American Journal of Medicine. 2000; 109(6): 476-840. PMid:11042237. http: //dx.doi.org/10.1016/S0002-9343(00)00531-3 
[26] Blodgett TJ. Reminder systems to reduce the duration of indwelling urinary catheters: a narrative review. Urological Nursing. 2009; 29(5): 369-379. PMid:19863044.

[27] Meddings J, Rogers MAM, Macy M, et al. Systematic review and meta-analysis: reminder systems to reduce catheter-associated urinary tract infections and urinary catheter use in hospitalized patients Clinical Infectious Diseases. 2010; 51(5): 550-560. PMid:20673003. http://dx.doi.org/10.1086/655133

[28] Loeb M, Hunt D, O'Halloran K, et al. Stop orders to reduce inappropriate urinary catheterization in hospitalized patients: a randomized controlled trial. Journal of General Internal Medicine. 2008; 23(6): 816-820. PMid:18421507. http://dx.doi.org/10.1007/s1160 6-008-0620-2

[29] Bruminhent J, Keegan M, Lakhani A, et al. Effectiveness of a simple intervention for prevention of catheter-associated urinary tract infections in a community teaching hospital. American Journal of Infection Control. 2010; 38(9): 689-693. PMid:21034979. http://dx.doi.org/10.1016/j.ajic.2010.05.028

[30] Cornia PB, Amory JK, Fraser S, et al. Computer-based order entry decreases duration of indwelling urinary catheterization in hospitalized patient. American Journal of Medicine. 2003; 114(5): 404407. PMid:127141431. http://dx.doi.org/10.1016/S0002-9 343 (02) 01568-1
[31] Bernard MS, Hunter KF, Moore KN. A review of strategies to decrease the duration of indwelling urethral catheters and potentially reduce the incidence of catheter-associated urinary tract infections. Urologic Nursing. 2012; 32(1): 29-37. PMid:22474863.

[32] Saint S, Kaufman SR, Thompson M, et al. A reminder reduces urinary catheterization in hospitalized patients. Joint Commission Journal on Quality and Patient Safety. 2005; 31(8): 455-462. PMid:16156193.

[33] Idvall E, Gunningberg L. Evidence for elective replacement of peripheral intravenous catheter to prevent thrombophlebitis: a systematic review. Journal of Advanced Nursing. 2006; 55(6): 715-722. PMid:16925620. http://dx.doi.org/10.1111/j.1365-2648. 2006.03962.x

[34] Webster J, Osborne S, Rickard C, et al. Clinically-indicated replacement versus routine replacement of peripheral venous catheters. The Cochrane Database of Systematic Reviews. 2015; 14(8): CD007798. PMid:26272489.

[35] Seguin P, Laviolle B, Isslame S, et al. Effectiveness of simple daily sensitization of physicians to the duration of central venous and urinary tract catheterization. Intensive Care Medicine. 2010; 36(7): 1202-1206. PMid:20237761. http://dx. doi.org/10.1007/s00 134-010-1829-1 